\title{
Discovery Learning dalam Pembelajaran PPKn
}

\section{Dwi Ustanti}

SDN 3 Jenengan Sawit Boyolali dwiustanti2@gmail.com

\section{Article History}

received 3/12/2020

\begin{abstract}
Education is a learning process so that active students are skilled, intelligent and have noble character. The purpose of this study (1) The students are active in learning, (2) The students are able to understand of PPKn (2) The students learning outcomes are increase. The results of this stusy is the students are active, understand of PPKn and the learning outcomes are increase.
\end{abstract}

Keywords: education, discovery learning, PPKn

\section{Abstrak}

Pendidikan adalah proses pembelajaran agar peserta didik yang aktif terampil, cerdas, dan berakhlak mulia. Tujuan penelitian ini (1) Siswa aktif dalam pembelajaran, (2) Siswa mampu memahami PPKn (2) Hasil belajar siswa meningkat. Hasil dari penelitian ini adalah siswa aktif, memahami PPKn dan hasil belajar meningkat.

Kata kunci: pendidikan, pembelajaran penemuan, PPKn 


\section{PENDAHULUAN}

Pendidikan merupakan proses pembelajaran agar peserta didik aktif, terampil, cerdas dan berakhlak mulia. Menurut Sanjaya (Ihdi Shabrona dkk, 2017 : 92) "Pendidikan adalah usaha sadar dan terencana untuk mewujudkan suasana belajar dan proses pembelajaran agar peserta didik secara aktif mengembangkan potensi dirinya untuk memiliki kekuatan spiritual keagamaan, pengendalian diri, kepribadian, kecerdasan dan akhlak mulia, serta keterampilan yang diperlukan dirinya untuk memiliki kekuatan spritual keagamaan, pengendalian diri, kepribadian, kecerdasan dan akhlak mulia, serta keterampilan yang diperlukan dirinya, masyarakat, bangsa, dan negara".

Pendidikan yang dimaksud bukan hanya bersifat nonformal akan tetapi bersifat formal, meliputi proses belajar mengajar yang melibatkan guru dan siswa. Peningkatan kualitas pendidikan siswa dapat dilihat dari instrumen prestasi belajarnya, Sedangkan keberhasilan atau prestasi belajar siswa dipengaruhi oleh proses belajar dari siswa itu sendiri. Jika dalam proses belajar bagus maka hasilnya akan maksimal tetapi sebaliknya jika dalam proses belajar siswa cenderung kurang bagus maka hasilnya tidak akan maksimal.

Menurut Fahmi sarofah (2019 : 222) Mata pelajaran Pendidikan Kewarganegaraan (PKn) merupakan salah satu program pendidikan yang dapat mengembangkan kemampuan berpikir kritis, sistematis, logis dan kreatif, serta kemampuan berkerja sama. Oleh karena itu, melihat pentingnya pendidikan kewarganegaraan dan peranannya dalam menghadapi perkembangan jaman dan IPTEK maka perlu dilakukan upaya dalam rangka meningkatkan mutu pendidikan kewarganegaraan pada semua jenis dan jenjang Pendidikan

Menurut Hudojo, dalam setiap kesempatan pembelajaran pendidikan kewarganegaraan hendaknya dimulai dengan pengenalan masalah yang sesuai dengan situasi (contextual problem). Dengan mengajukan masalah kontektual, siswa secara bertahap dibimbing untuk menguasai konsep pendidikan kewarganegaraan. Untuk meningkatkan keefektifan pembelajaran, paradigma belajar pendidikan kewarganegaraan lebih tepat mendasarkan pada pandangan konstruktivistik, karena pandangan kontruktivistik merupakan landasan berpikir kontekstual, pengetahuan dibangun sedikit demi sedikit, yang hasilnya diperluas melalui konteks yang terbatas dan tidak dengan tiba-tiba.

Upaya untuk meningkatkan mutu pendidikan harus dilakukan dengan menggerakan seluruh komponen dalam pendidikan. Salah satu aspek yang harus ditingkatkan yaitu proses belajar mengajar. Dalam Permendikbud Nomor 22 Tahun 2016 menyatakan bahwa, "Proses Pembelajaran pada satuan pendidikan diselenggarakan secara interaktif, inspiratif, menyenangkan, menantang, memotivasi, peserta didik untuk berpartisipasi aktif, serta memberikan ruang yang cukup bagi prakasa, kreativitas, dan kemandirian sesuai dengan bakat, minat, perkembangan fisik serta psikologis siswa. Dengan demikian, setiap satuan pendidikan melakukan perencanaan pembelajaran, pelaksanaan proses pembelajaran serta penilaian proses pembelajaran untuk meningkatkan efisiensi dan efektivitas ketercapaian kompetensi lulusan". Melihat dari hal tersebut guru sangatlah penting dalam meningkatkan kemampuan siswa, prestasi yang dicapai siswa agar mencapai tujuan pembelajaran serta kreativitas siswa (Menurut Endah setyowati 2018 : 1).

Hal tersebut memperkuat anggapan bahwa guru dituntut untuk lebih kreatif lagi dalam proses belajar - mengajar, agar tercipta suasana belajar yang menyenangkan pada diri siswa yang pada akhirnya meningkatkan motivasi belajar siswa. Salah satu alternatif untuk memperbaiki kondisi pembelajaran yang dipaparkan tersebut di atas adalah model pembelajaran yang tepat bagi siswa serta dapat memecahkan masalah yang dihadapi. Model pembelajaran adalah tolak ukur untuk menentukan terjadinya proses belajar mengajar yang selanjutnya menentukan hasil belajar. Berhasil atau 
tidaknya proses belajar mengajar tergantung pada pendekatan, metode, serta teknik mengajar yang dilakukan oleh guru. Oleh sebab itu, guru diharapkan selektif dalam menentukan dan menggunakan model pembelajaran. Dalam proses pembelajaran, guru harus menguasai prinsip-prinsip belajar mengajar serta mampu menerapkan dalam proses belajar mengajar. Prinsip - prinsip belajar mengajar yang dimaksud disini adalah model pembelajaran yang tepat untuk suatu materi pelajaran tertentu.

Kegiatan belajar-mengajar hendaknya tidak hanya berfokus pada guru, tetapi juga harus melibatkan siswa. Artinya pembelajaran harus melibatkan kemampuan siswa secara maksimal untuk menggali dan mengidentifikasi sehingga mereka dapat menemukan pengetahuan dengan sendiri. Pembelajaran ini disebut pembelajaran penemuan (Discovery Learning).

Melatihkan kecakapan berpikir akan membantu siswa dalam menyelesaikan masalah, terutama masalah-masalah yang ada disekitar siswa. Sehingga siswa mampu secara kreatif menemukan ide-ide dalam penyelesaian masalah tersebut. Selain itu, dengan melatikan siswa untuk menyelesaikan maslah-masalah yang ada di sekitar siswa, maka siswa tidak akan merasa jenuh dengan pembelajaran yang hanya monoton (Menurut Irsad, 2016:56).

Model pembelajaran discovery merupakan suatu metode pengajaran yang menitikberatkan pada aktivitas siswa dalam belajar. Dalam proses pembelajaran dengan metode discovery learning, guru hanya bertindak sebagai pembimbing dan fasilitator yang mengarahkan siswa untuk menemukan konsep, dalil, prosedur, algoritma dan semacamnya. Model pembelajaran discovery mengutamakan cara belajar siswa aktif (CBSA), berorientasi pada proses, mengarahkan sendiri, mencari sendiri dan reflektif. Dalam makalah ini akan membahas mengenai pengertian discovery learning dan bagaimana karakteristik serta tahapannya dalam proses pembelajaran.

Menurut Rizky Puspita dewi dkk, (2016 : 115) bahwa model pembelajaran Discovery Learning menekankan pentingnya pemahaman suatu konsep melalui keterlibatan siswa secara aktif dalam proses pembelajaran. Model pembelajaran ini menekankan pada pembentukan pengetahuan siswa dari pengalaman selama pembelajaran.

\section{HASIL DAN PEMBAHASAN}

Menurut Alfauzan (2015: 6) Model pembelajaran adalah bentuk pembelajaran yang tergambar dari awal sampai akhir yang disajikan secara khas oleh guru di kelas. Dalam model pembelajaran terdapat strategi pencapaian kompetensi siswa dengan pendekatan, metode, dan teknik pembelajaran. (Menurut Alfauzan 2018:37) Model yang digunakan dalam proses pembelajaran sangat berpengaruh terhadap penguasaan siswa terhadap pesan yang diberikan, dengan kata lain, dalam proses pembelajaran jika model yang digunakan oleh guru tidak sesuai dengan kondisi maka hasil proses belajar mengajarpun tidak akan maksimal.

1. Definisi Model Pembelajaran Discovery Learning

Discovery Learning adalah suatu proses belajar yang di dalamnya tidak disajikan suatu konsep dalam bentuk jadi (final), akan tetapi siswa dituntut untuk mengorganisasi sendiri cara belajarnya dalam menemukan konsep. Sebagaimana pendapat Bruner (Kemendikbud, 2013:242) bahwa: "Discovery Learning can be defined as the learning that takes place when the student is not presented with subject matter in the final form, but rather is required to organize it him self". Dasar ide teori Bruner adalah pendapat dari Piaget yang menyatakan bahwasanya anak harus berperan aktif dalam belajar di kelas.

Ellyza, (2015: 34) menyatakan bahwa "Discovery Learning merupakan pembelajaran berdasarkan penemuan (inquiry-based), konstruktivis dan teori bagaimana belajar. Model pembelajaran yang diberikan kepada siswa memiliki 
skenario pembelajaran untuk memecahkan masalah yang nyata dan mendorong mereka untuk memecahkan masala mereka sendiri. Dalam memecahkan masalah yang dihadapi, karena bersifat konstruktivis, para siswa menggunakan pengalaman mereka terdahulu dalam memecahkan masalah. Kegiatan yang dilakukan ialah berinteraksi untuk menggali, mempertanyakan selama bereksperimen dengan teknik trial and error"

Model pembelajaran discovery learning merupakan model yang mengatur segala pengajaran sehingga siswa mendapatkan pengetahuan baru melalui model penemuan yang ditemukan sendiri. Seorang guru memberikan ruang kepada siswanya untuk dapat berdiri sendiri mendorong siswa untuk mandiri guna memperoleh pengetahuan baru.

Discovery learning merupakan suatu model pemecahan masalah yang akan bermanfaat bagi anak didik dalam menghadapi kehidupannya di kemudian hari. Penerapan model discovery learning ini bertujuan agar siswa mampu memahami materi perubahan wujud benda dengan sebaik mungkin dan pembelajaran lebih terasa bermakna, sehingga hasil belajar siswa pun akan meningkat. Karena model discovery learning ini dalam prosesnya menggunakan kegiatan dan pengalaman langsung sehingga akan lebih menarik perhatian anak didik dan memungkinkan pembentukan konsep-konsep abstrak yang mempunyai makna, serta kegiatannya pun lebih realistis.

Penemuan (discovery) merupakan model pembelajaran yang dikembangkan berdasarkan pandangan konstruktivisme. Model penemuan (discovery) ini, menekankan pentingnya pemahaman struktur atau ide-ide penting terhadap suatu disiplin ilmu, melalui keterlibatan siswa secara aktif dalam proses pembelajaran. Penemuan merupakan suatu strategi yang unik dapat diberi bentuk oleh guru dalam berbagai cara, termasuk mengajarkan berbagai keterampilan menyelidiki dan memecahkan masalah sebagai alat bagi siswa untuk mencapai tujuan pendidikannya. Dalam pembelajaran dengan penemuan (discovery), siswa didorong untuk belajar sebagian besar melalui keterlibatan aktif mereka sendiri dengan konsep-konsep dan prinsip-prinsip, dan guru mendorong siswa untuk memiliki pengalaman dan melakukan percobaan yang memungkinkan siswa untuk dapat menemukan sendiri prinsip-prinsip untuk diri mereka sendiri. Dengan demikian dapat dikatakan bahwa model penemuan itu adalah suatu metode di mana dalam proses belajar mengajar guru memperkenankan siswa-siswanya menemukan sendiri informasi yang secara tradisional biasa diberitahukan atau diceramahkan saja.

Belajar penemuan adalah suatu proses belajar yang terjadi sebagai hasil dari siswa memanipulasi, membuat struktur dan mentransformasikan informasi sedemikian sehingga ia menemukan informasi baru. Dalam belajar penemuan (discovery), siswa dapat membuat perkiraan, merumuskan suatu hipotesis dan menemukan kebenaran dengan menggunakan proses induktif atau proses dedukatif, melakukan observasi dan membuat ekstrapolasi. Pembelajaran penemuan ialah merupakan salah satu model pembelajaran yang digunakan dalam pendekatan konstruktivis modern. Pada pembelajaran penemuan, siswa didorong untuk belajar sendiri melalui keterlibatan aktif dengan konsep-konsep dan prinsip-prinsip. Guru mendorong para siswa agar mempunyai pengalaman dan melakukan eksperimen dengan memungkinkan mereka menemukan prinsip-prinsip atau konsep-konsep bagi diri mereka sendiri. Belajar penemuan mengakibatkan keingintahuan siswa, memberi motivasi untuk bekerja terus sampai menemukan jawaban. Lagi pula model ini dapat mengajarkan keterampilanketerampilan memecahkan masalah tanpa pertolongan orang lain, dan meminta para siswa untuk menganalisis dan memanipulasi, tidak hanya menerima saja.

Menurut Salmon (2012:4) dalam pengaplikasiannya model Discovery Learning mengembangkan cara belajar siswa aktif dengan menemukan sendiri, menyelidiki sendiri, maka hasil yang diperoleh akan tahan lama dalam ingatan, Serta posisi guru di 
kelas sebagai pembimbing dan mengarahkan kegiatan pembelajaran sesuai dengan tujuan. Kondisi seperti ini tujuannya adalah ingin merubah kegiatan belajar mengajar yang teacher oriented menjadi student oriented.

2. Kelebihan dan kekurangan model discovery learning

(Kemendikbud 2013) Kelebihan model discovery learning adalah sebagai berikut:

a. Membantu siswa untuk memperbaiki dan meningkatkan keterampilan-keterampilan serta proses-proses kognitif. Usaha penemuan merupakan kunci dalam proses ini.

b. Metode ini memungkinkan siswa berkembang dengan cepat dan sesuai dengan kecepatannya sendiri.

c. Meningkatkan tingkat penghargaan pada siswa, karena unsur berdiskusi.

d. Menimbulkan rasa senang pada siswa, karena tumbuhnya rasa menyelidiki dan berhasil.

e. Membantu siswa menghilangkan skeptisme (keragu-raguan) karena mengarah pada kebenaran yang final dan tertentu atau pasti

berikut:

Sementara itu kekurangannya menurut Kemendikbud (2013) adalah sebagai

a) Metode ini menimbulkan asumsi bahwasanya ada kesiapan pikiran untuk belajar. Bagi siswa yang kurang pandai, mereka akan mengalami kesulitan berfikir atau mengungkapkan hubungan antara konsep-konsep, yang tertulis atau lisan, sehingga pada gilirannya akan menimbulkan frustasi.

b) Metode penemuan (discovery) tersebut kurang efisien untuk pembelajaran dalam jumlah siswa yang banyak, karena membutuhkan waktu yang lama untuk membantu mereka menemukan teori atau pemecahan masalah lainnya.

c) Harapan-harapan yang terkandung dalam metode discovery dapat buyar berhadapan dengan siswa dan guru yang telah terbiasa dengan cara-cara belajar yang lama.

d) Pengajaran penemuan (discovery) lebih cocok untuk mengembangkan pemahaman, sedangkan mengembangkan aspek konsep, keterampilan dan emosi secara keseluruhan kurang mendapat perhatian.

e) Tidak menyediakan kesempatan-kesempatan untuk berpikir yang akan ditemukan oleh siswa karena telah dipilih terlebih dahulu oleh guru.

Berdasarkan pengertian di atas dapat disimpulkan bahwa model pembelajaran discovery learning adalah model pembelajaran yang mengatur sedemikian rupa sehingga anak memperoleh pengetahuan yang belum diketahuinya itu tidak melalui pemberitahuan, sebagian atau seluruhnya ditemukan oleh diri sendiri. Dalam pembelajaran penemuan (discovery), mulai dari strategi sampai dengan jalan dan hasil penemuan ditentukan oleh siswa sendiri. Pembelajaran discovery learning merupakan suatu model untuk mengembangkan cara belajar siswa aktif dengan menemukan sendiri, menyelidiki sendiri, maka hasil yang diperoleh akan setia dan tahan lama dalam ingatan, tidak akan mudah dilupakan siswa. Dengan belajar penemuan (discovery), anak juga bisa belajar berfikir analisis dan mencoba memecahkan sendiri problem yang sedang dihadapi. Kebiasaan ini akan di transfer dalam kehidupan bermasyarakat.

\section{Langkah-langkah Model Pembelajaran Discovery Learning}

(Menurut Zulastri 2017:21) Langkah-langkah Pelaksanaan Model Pembelajaran Discovery Learning

a. Stimulasi (stimulation).

Pada kegiatan ini guru memberikan stimulan, dapat berupa bacaan, gambar, dan cerita sesuai dengan materi pembelajaran yang akan dibahas, sehingga peserta didik 
mendapat pengalaman belajar melalui kegiatan membaca, mengamati situasi atau melihat gambar.

b. Identifikasi masalah (problem statement).

Pada tahap ini peserta didik diharuskan menemukan permasalahan apa saja yang dihadapi dalam pembelajaran, mereka diberi pengalaman untuk menanya, mengamati, mencari informasi, dan mencoba merumuskan masalah.

c. Pengumpulan data (data collecting).

Pada tahap ini pesertadidik diberikan pengalaman mencari dan mengumpulkan informasi yang dapat digunakan untuk menemukan alternative pemecahan masalah yang dihadapi.

d. Pengolahan data (data processing).

Kegiatan mengolah data akan melatih peserta didik untuk mencoba dan mengeksplorasi kemampuan konseptualnya untuk diaplikasikan pada kehidupan nyata, sehingga kegiatan ini juga akan melatih keterampilan berpikir logis dan aplikatif.

e. Verifikasi (verification).

Tahap ini mengarahkan peserta didik untuk mengecek kebenaran dan keabsahan hasil pengolahan data, melalui berbagai kegiatan, antara lain bertanya kepada teman, berdiskusi, dan mencari berbagai sumber yang relevan, serta mengasosiasikannya, sehingga menjadi suatu kesimpulan.

f. Generalisasi (generalization).

Pada kegiatan ini peserta didik digiring untuk menggeneralisasikan hasil simpulannya pada suatu kejadian atau permasalahan yang serupa, sehingga kegiatan ini juga dapat melatih pengetahuan metakognisi peserta didik.

\section{SIMPULAN}

Discovery learning merupakan suatu model pemecahan masalah yang akan bermanfaat bagi anak didik dalam menghadapi kehidupannya di kemudian hari. Penerapan model discovery learning ini bertujuan agar siswa aktif, mampu memahami materi PPKn dengan sebaik mungkin dan pembelajaran lebih terasa bermakna, sehingga hasil belajar siswa pun akan meningkat. Karena model discovery learning ini dalam prosesnya menggunakan kegiatan dan pengalaman langsung sehingga akan lebih menarik perhatian anak didik dan memungkinkan pembentukan konsep-konsep abstrak yang mempunyai makna, serta kegiatannya pun lebih realistis.

\section{DAFTAR PUSTAKA}

Amin, Alfauzan. (2015). Metode \& Model Pembelajaran Agama Islam (Bengkulu: IAIN Bengkulu Press

Amin,Alfauzan. (2018). Model Pembelajaran Agama Islam Di Sekolah, Yogyakarta: Samudra Biru

Kemendikbud. (2013). Materi Pelatihan Guru Implementasi Kurikulum 2013 SMP/MTs matematika. Jakarta: Kementrian Pendidikan Dan Kebudayaan.

Kemendikbud. (2013). Modul Kurikulum 2013. Jakarta: Kementrian Pendidikan Dan Kebudayaan.

Puspita dewi,Rizky, Agung Nugroho Catur Saputro dan Ashadi. (2016). Penerapan Model Pembelajaran Discovery Learning untuk Meningkatkan Minat dan Prestasi Belajar Siswa Pada Materi Kelarutan dan Hasil Kali Kelarutan Kelas XI Mia 3 Semester Genap SMA N 1 Teras Tahun Pelajaran 2015/2016. Jurnal Pendidikan Kimia, Universitas Sebelas Maret. Volume 5, No 4, hal.115

Putri,Ibdi Shabrona, Rita Juliani dan Ilan Nia Lestari. (2017). Pengaruh Model Pembelajaran Discovery Learning Terhadap Hasil Belajar Siswa Dan Aktivitas Siswa. Jurnal Pendidikan Fisika, Universitas Negeri Medan. Volume 6, Nomor 2, hal.92 
Rosidi,Irsad. (2016). Pengembangan Lembar Kegiatan Siswa Berorientasi Pembelajaran Penemuan Terbimbing (Guided Discovery Learning) Untuk Melatihkan Keterampilan Proses Sains. Jurnal Pena Sains, Universitas Tranjoyo Madura Bangkalan. Volume 3 Nomor 1 April 2016, hal.56

Salmon, A. et al. (2012). Belajar dan Pembelajaran Matematika Model Pembelajaran Discovery Learning. Makalah Universitas Patimura Ambon: tidak diterbitkan.

Setyowati1, Endah dkk. (2018). Penggunaan Model Pembelajaran Discovery Learning Untuk Meningkatkan Kreativitas dan Hasil Belajar Siswa Kelas 5 Sd Negeri Mangunsari 07, Jurnal Sains dan Teknologi, Vol. 1

Syarofah, Fahmi dkk. (2019). Penerapan Metode Discovery Learning dan Ekspositori Terhadap Peningkatan Hasil Belajar Pkn Siswa Kelas 7 Smp Negeri 2 dan Smp Negeri 7 Bangkalan, Jurnal Education and development Institut Pendidikan Tapanuli Selatan, Vol.7 No.2

Widyastuti, Ellyza Sri. (2015). Penerapan Model Pembelajaran Discovery Learning Pada Materi Konsep IImu Ekonomi. Prosiding Seminar Nasional 9 Mei 2015, Universitas Negeri Surabaya, hal.34

Zulastri, "Pengaruh Penggunaan Model Pembelajaran Discovery Learning Terhadap Hasil Belajar Pada Mata Pelajaran Matematika Materi Sifat Bangun Datar Siswa Kelas lii Mi Nurul Islam Semarang Tahun Ajaran 2016/ 2017," (Skripsi S1 Fakultas IImu Tarbiyah dan Keguruan, Universitas Islam Negeri Walisongo Semarang, 2017), h. 21. 